Available online at http://journal.stkip-andi-matappa.ac.id/index.php/histogram/index

Histogram : Jurnal Pendidikan Matematika 4(1), 2020, 30 - 44

\title{
KOMPARASI KEMAMPUAN PEMAHAMAN, KONEKSI DAN KOMUNIKASI MATEMATIS PADA TIPE STAD DAN TAI
}

\author{
Amiruddin ${ }^{1}$, Esterina Natalia Paindan ${ }^{2}$ \\ 1,2) STT Migas Balikpapan \\ * Corresponding Author. Email: amir_bppn@yahoo.com \\ Received: 06 Februari 2020; Revised: 27 Februari 2020 ; Accepted: 30 Maret 2020
}

\begin{abstract}
ABSTRAK
Penelitian ini bertujuan untuk mengetahui perbedaan kemampuan pemahaman, koneksi, dan komunikasi matematis siswa dalam penerapan model pembelajaran kooperatif tipe STAD dan tipe TAI pada siswa SMP Negeri 14 Balikpapan ditinjau dari kemampuan awal matematika (tinggi dan rendah). Penelitian ini adalah penelitian eksperimen, dengan populasi seluruh siswa SMP Negeri 14 Balikpapan, dan sampel berasal dari empat kelas yakni dua kelas untuk kelas eksperimen I dengan penerapan model pembelajaran kooperatif tipe STAD dan dua kelas untuk kelas eksperimen II dengan penerapan model pembelajaran kooperatif tipe TAI, teknik yang digunakan yaitu teknik purposive sampling. Data yang dikumpulkan terdiri atas data tes kemampuan awal matematika, tes kemampuan pemahaman, koneksi, dan komunikasi matematis, lembar observasi keterlaksanaan pembelajaran, lembar observasi akltifitas siswa, dan angket respons siswa. Data dianalisis dengan menggunakan analisis deskriptif dan analisis inferensial. Hasil penelitian untuk uji hipotesis pada taraf signifikansi $\alpha=0,05$ diperoleh kesimpulan bahwa kemampuan pemahaman, koneksi, dan komunikasi matematis siswa yang diajar dengan menerapkan model pembelajaran kooperatif tipe TAI lebih baik dari tipe STAD ditinjau dari kemampuan awal matematika.
\end{abstract}

Kata kunci: Komparasi, Pemahaman, Koneksi, Komunikasi, Matematis

\section{ABSTRACT}

The research which aimed to discover the difference of understanding ability, connection, and mathematical communication in the implementation of cooperative learning model of STAD type and TAI type to the students of SMP Negeri 14 Balikpapan based on mathematics initial ability (high and low). The research was experiment research. The population was all of the students of SMP Negeri 14 Balikpapan. The samples were selected by conducting purposive sampling and obtained four class, namely two class for experiment class I which taught by implementing cooperative learning model of STAD type and two class for experiment class II which taught by cooperative learning model of TAI. The data collection consisted of data of mathematics initial ability test, understanding ability test, connection, and mathematical communication, learning implementation observation sheet, students' activity observations sheet, and students' response questionnaire. The data were anlyzed bu using desciptive and inferential analysis. The result for hypotesis test in the level of significance $\alpha=0.05$ obtained conclusion that understanding ability, connection, and mathematical communication of the students who were taught by implementing cooperative learning model of TAI type were better than STAD type based on mathematics initial ability

Keywords: Comparison, Understanding, Connection, Communication, Mathematic

How to Cite: Amiruddin., \& Paindan, E, N. (2020). Komparasi Kemampuan Pemahaman, Koneksi dan Komunikasi Matematis Pada Tipe STAD Dan TAI. Histogram: Jurnal Pendidikan Matematika, 4(1), 30 - 44, doi: http://dx.doi.org/10.31100/histogram.v4i1.521

Permalink/DOI: http://dx.doi.org/10.31100/histogram.v4i1.521

Copyright(C) 2020, THE AUTHOR (S). This article distributed under the CC-BY-SA-license.

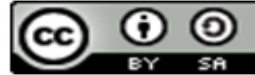




\section{Histogram: Jurnal Pendidikan Matematika, 4(1), 2020 - 31 Amiruddin', Esterina Natalia Paindan²}

\section{PENDAHULUAN}

Dalam kurikulum salah satu tujuan mata pelajaran matematika di tingkat SMP yaitu siswa memiliki kemampuan memahami konsep matematika, menjelaskan keterkaitan antar konsep dan menerapkan konsep atau algoritma secara luwes akurat, efisien, dan tepat dalam pemecahan masalah. Hal ini menjelaskan bahwa perlu dikembangkan kemampuan pemahaman matematis dalam pembelajaran matematika di tingkat SMP. Hal ini dipertegas dengan adanya pernyataan NCTM (Hikmah, 2017) disebutkan pula bahwa aspek penting dalam pembelajaran matematika adalah kemampuan pemahaman matematis. Berdasarkan data TIMSS (Putra et al., 2018) menunjukkan bahwa lemahnya kemampuan pemahaman matematis siswa dalam menyelesaikan masalah soal-soal tidak rutin. Beberapa faktor yang mempengaruhi kemampuan pemahaman matematis siswa, seperti model pembelajaran, tingkat perkembangan kognitif siswa, dan cara belajar siswa.

Kemampuan pemahaman Anderson et al. (Syarifah, 2017) terdiri dari tujuh jenis, yaitu interpreting (menginterpretasikan), exemplifying (memberikan contoh), classifying (mengklasifikasikan), summarizing (meringkas), inferring (menyimpulkan), comparing (membandingkan), dan explaining (menjelaskan). Sedangkan indikator pemahaman konsep menurut kurikulum 2006 (Sari et al., 2016) yaitu menyatakan ulang sebuah konsep, mengklasifikasikan objek-objek menurut sifat-sifat tertentu (sesuai dengan konsepnya), memberikan contoh dan non contoh dari konsep, menyajikan konsep dalam berbagai bentuk representasi matematis, mengembangkan syarat perlu atau syarat cukup suatu konsep, menggunakan, memanfaatkan, dan memilih prosedur atau operasi tertentu, dan mengaplikasikan konsep atau algoritma pemecahan masalah. Dari beberapa pendapat tersebut, dapat disimpulkan bahwa pemahaman matematis adalah pengetahuan siswa tentang konsep, prinsip, prosedur, dan kemampuan siswa menggunakan strategi penyelesaian terhadap suatu masalah yang disajikan. Seseorang yang telah memiliki kemampuan pemahaman matematis berarti orang tersebut telah mengetahui apa yang dipelajarinya, langkah-langkah yang dilakukan, dapat menggunakan matematika dalam konteks matematika dan di luar konteks matematika. Untuk keperluan penelitian ini pemahaman matematis dibatasi pada aspek-aspek pemahaman konsep dan pemahaman relasional dengan indikator untuk pemahaman konsep meliputi kemampuan siswa menginterpretasikan, mengklasifikasikan objek-objek menurut 


\section{Histogram: Jurnal Pendidikan Matematika, 4(1), 2020 - 32 Amiruddin', Esterina Natalia Paindan²}

sifat-sifat tertentu, menjelaskan, merumuskan dan melakukan perhitungan dalam matematika, selanjutnya untuk indikator pemahaman relasional meliputi kemampuan siswa membandingkan atau menggunakan matematika dalam konteks matematika di dalam maupun di luar matematika.

Begitu pula dengan pemahaman matematis bahwa koneksi matematis juga sangat penting, kemampuan koneksi matematis merupakan aspek kemampuan matematis yang penting dalam kegiatan belajar matematika yang harus dicapai, dengan mengetahui kaitan atau hubungan matematika, dalam memahami matematika menjadi lebih mudah dan menambah pengetahuan matematika mereka yang lebih besar. Hal ini sejalan dengan pendapat Hirdjan (Latipah \& Afriansyah, 2018) yang menyatakan bahwa matematika tidak diajarkan secara terpisah antar topik, masing-masing topik bisa dilibatkan atau terlibat dengan topik lainnya. Oleh karena itu, pemahaman siswa pada suatu topik akan membantu untuk memahami topik yang lain, tetapi hal ini bisa terjadi jika siswa mampu mengkoneksikan topik-topik tersebut. Bruner (Heryani \& Eptiani, 2016) juga menjelaskan bahwa untuk memperoleh hasil matematika yang lebih baik, siswa diberi kesempatan yang lebih banyak untuk melihat kaitan atau hubungan, baik kaitan, antara teori dengan teori, antara dalil dengan dalil, antara topik dengan topik, maupun antara cabang matematika.

Dalam hal kegiatan belajar matematika, siswa melakukan aktifitas-aktifitas belajar seperti menerima, mengolah atau mengungkapkan ide-ide atau gagasan-gagasan dalam matematika. Untuk mengaitkan atau menghubungkan berbagai macam ide atau gagasan matematis yang diperoleh siswa, diperlukan suatu kemampuan koneksi matematis. NCTM juga menetapkan bahwa kemampuan koneksi matematis merupakan kemampuan standar yang telah ditetapkan dan diberbagai negara juga telah menerapkannya. Sejalan dengan Sumarmo (Maulida et al., 2019) mengemukakan koneksi dalam matematika merupakan hubungan dari ide-ide atau gagasan yang digunakan untuk merumuskan dan menguji topik-topik matematika secara deduktif.

Kemampuan koneksi dalam matematika sangat penting untuk dikembangkan, Mousley (Supriadi, 2015) menjelaskan bahwa aktifitas penting yang harus dilaksanakan oleh guru dan siswa dalam pembelajaran matematika agar pemahaman matematis siswa dapat terbentuk yaitu dengan membangun koneksi matematika. Ada tiga macam koneksi matematis yang perlu dikembangkan menurut Mousley (Supriadi, 2015) yaitu: (a) koneksi antara pengetahuan 


\section{Histogram: Jurnal Pendidikan Matematika, 4(1), 2020 - 33}

\section{Amiruddin', Esterina Natalia Paindan²}

matematika baru dengan pengetahuan matematika yang sudah ada sebelumnya; (b) koneksi antar konsep-konsep matematika, dan (c) koneksi antara matematika dengan kehidupan seharihari. Indikator ini untuk menyusun tes kemampuan koneksi matematis.

Dilain hal yang juga sangat penting untuk dikembangkan dalam pembelajaran matematika disamping kemampuan pemahaman matematis dan koneksi matematis adalah kemampuan komunikasi matematis. Dalam mengkomunikasikan gagasan atau ide dengan simbol, diagram, tabel atau media lain untuk memperjelas keadaan atau masalah merupakan tujuan utama pembelajaran matematika. Sesuai dengan (Sriwahyuni et al., 2019) komunikasi matematis penting untuk dikembangkan lebih lanjut, hal ini disebabkan komunikasi merupakan suatu kegiatan yang sangat penting dalam menjalani kehidupan sehari-hari, dimana pada komunikasi terjadi aktifitas penyampaian informasi, baik itu pesan, ide atau gagasan, dari satu pihak ke pihak lainnya.

Siswa yang memiliki kemampuan pemahaman dan koneksi matematis diharuskan juga untuk dapat mengkomunikasikannya, agar pemahamannya tersebut dapat dimengerti dan dipahami oleh orang lain. Untuk dapat meningkatkan kemampuan pemahaman matematisnya, siswa dapat mengkomunikasikan gagasan atau ide matematisnya kepada orang lain. Seperti pendapat Huggins (Rahman, dkk, 2018) bahwa untuk dapat meningkatkan kemampuan pemahaman konseptual matematisnya, siswa bisa melakukannya dengan mengemukakan gagasan atau ide matematisnya kepada orang lain. Adapun pada penelitian ini, indikator untuk mengukur kemampuan komunikasi matematis siswa dalam mengungkapkan kemampuan komunikasi matematisnya secara tertulis pada permasalahan matematika, yaitu: kemampuan dalam menyatakan serta mengilustrasikan gagasan atau ide matematika ke dalam bentuk model matematika yaitu bentuk persamaan, notasi, gambar dan grafik, ataupun sebaliknya.

Berdasarkan latar belakang di atas bahwa kemampuan pemahaman, koneksi serta komunikasi matematis sangat penting, maka untuk mengembangkan hal itu dalam penelitian ini akan diterapkan model pembelajaran kooperatif tipe STAD dan TAI. Hal ini dikarenakan model pembelajaran kooperatif tipe STAD dan TAI merupakan model pembelajaran yang lebih mengutamakan kelompok-kelompok heterogen dalam mencapai tujuan pembelajaran mengharuskan kerja sama dalam menyelesaikan setiap permasalahan. Hal ini sejalan dengan pendapat (Harsanti, 2017) model pembelajaran kooperatif merupakan bentuk pembelajaran dengan cara siswa belajar dan bekerja dalam kelompok-kelompok kecil secara kolaboratif yang

ISSN: 2549-6700 (print), ISSN 2549-6719 (online) 


\section{Histogram: Jurnal Pendidikan Matematika, 4(1), 2020 - 34 \\ Amiruddin', Esterina Natalia Paindan²}

anggotanya terdiri dari empat sampai enam orang dengan struktur kelompok yang bersifat heterogen, dalam kegiatan diskusi kelompok, bekerja sama secara kelompok, berpartipasi aktif, dalam memahami konsep dan memecahkan permasalahan untuk mencapai prestasi akademik yang baik.

Dalam proses pembelajaran model kooperatif tipe STAD dan tipe TAI siswa diharuskan untuk bekerja sama pada suatu tugas bersama dan mereka harus mengkoordinasikan usahanya dalam menyelesaikan tugas yang telah diberikan guru. Pada prinsipnya bahwa model pembelajaran kooperatif tipe STAD dan tipe TAI adalah tanggung jawab. Dalam pembelajaran kooperatif tipe STAD dan tipe TAI dikembangkan komunikasi dan diskusi dengan harapan agar siswa saling berbagi kemampuan, saling menyampaikan pendapat, saling memberi kesempatan menyalurkan kemampuan, saling berpikir kritis, saling membantu belajar, saling menilai kemampuan dan peranan diri sendiri maupun teman lain. Sehingga model pembelajaran kooperatif tipe STAD dan tipe TAI dapat meningkatkan pemahaman, koneksi dan komunikasi matematis.

Dari beberapa penjelasan di atas mengenai model pembelajaran kooperatif tipe STAD dan model pembelajaran kooperatif tipe TAI, oleh karena itu peneliti tertarik melakukan studi komparasi yaitu untuk mengetahui perbedaan kemampuan pemahaman, koneksi serta komunikasi matematis siswa yang ditinjau dari kemampuan awal matematika antara siswa yang diberikan perlakuan model pembelajaran kooperatif tipe STAD dengan siswa yang diberikan perlakuan model pembelajaran kooperatif tipe TAI. Penelitian ini relevan dengan penelitian yang dilakukan oleh (Harsanti, 2017) dengan membandingankan model pembelajaran STAD dengan model TAI terhadap hasil belajar matematika siswa kelas V sekolah dasar, dan juga penelitian yang dilakukan oleh (Nisa \& Hanggara, 2017) dengan melakukan perbandingan model pembelajaran kooperatif tipe STAD dengan tipe TAI terhadap hasil belajar matematika ditinjau dari kemampuan awal siswa MAN 1 Batam. Penelitian ini berbeda dengan penelitian sebelumnya, dengan adanya penambahan variabel penelitian tentang kemampuan pemahaman, koneksi, dan kemampuan komunikasi matematis.

Mengacu pada latar belakang diatas, maka tujuan dalam penelitian ini ingin mengetahui apakah kemampuan pemahaman, komunikasi dan koneksi matematis siswa dalam penerapan model pembelajaran kooperatif tipe TAI lebih baik daripada model pembelajaran kooperatif tipe STAD pada siswa SMP Negeri 14 Balikpapan ditinjau dari kemampuan awal matematika.

ISSN: 2549-6700 (print), ISSN 2549-6719 (online) 


\section{Histogram: Jurnal Pendidikan Matematika, 4(1), 2020 - 35}

\section{Amiruddin', Esterina Natalia Paindan²}

\section{METODE PENELITIAN}

Penelitian ini dilakukan di SMP Negeri 14 Balikpapan Tahun Ajaran 2019/2020. Penelitian ini dikategorikan ke dalam penelitian eksperimen. Dikatakan eksperimen karena peneliti ingin memberikan perlakuan pada empat kelas. Perlakuan untuk dua kelas pada kelompok eksperimen pertama yaitu pembelajaran matematika dengan model pembelajaran kooperatif tipe STAD, dua kelas pada kelompok eksperimen kedua yaitu pembelajaran matematika dengan model pembelajaran kooperatif tipe TAI.

Sampel dalam penelitian ini ditentukan dengan menggunakan teknik purposive sampling. Sampel penelitian dari populasi dipilih secara langsung empat kelas dari sepuluh kelas siswa kelas VIII pada SMP N 14 Balikpapan, hal ini dilakukan dengan pertimbangan bahwa kelas sampel penelitian yang diambil mendapat materi dengan kurikulum yang sama, menggunakan buku paket yang sama, siswa duduk pada tingkat kelas yang sama, serta mempunyai karakteristik yang sama dilihat dari kemampuan akademik yaitu terdiri dari siswa yang mempunyai kemampuan tinggi, sedang dan rendah.

Penelitian ini menggunakan pretest-posttest control group design. Berikut ini adalah bagan desainnya:

Tabel 1. Desain Penelitian

\begin{tabular}{cccc}
\hline Kelompok & Pretest & Treatment & Posttest \\
\hline $\mathrm{E}_{1}$ & $\mathrm{O}_{1}$ & $\mathrm{~T}_{1}$ & $\mathrm{O}_{2}$ \\
\hline $\mathrm{E}_{2}$ & $\mathrm{O}_{1}$ & $\mathrm{~T}_{2}$ & $\mathrm{O}_{2}$ \\
\hline
\end{tabular}

Keterangan:

(Sumber: Sugiyono, Tahun: 2011)

E1 : Kelompok eksperimen pertama

E2 : Kelompok eksperimen kedua

O1 : Pretest

$\mathrm{O} 2$ : Postest

T1 : Perlakuan terhadap kelompok kelas eksperimen pertama yaitu menerapkan model pembelajaran kooperatif tipe STAD

T2 : Perlakuan terhadap kelompok kelas eksperimen kedua yaitu menerapkan model pembelajara kooperatif tipe TAI

Penelitian ini melibatkan variabel bebas dan varibel terikat. Adapun variabel bebasnya adalah pembelajaran model kooperatif tipe STAD dan tipe TAI. Sedangkan variabel terikatnya adalah kemampuan pemahaman, koneksi serta komunikasi matematis. Selain itu, dalam 


\section{Histogram: Jurnal Pendidikan Matematika, 4(1), 2020 - 36 \\ Amiruddin', Esterina Natalia Paindan²}

penelitian ini juga dilibatkan variabel kontrol, yaitu kemampuan awal matematika (tinggi, dan rendah).

Untuk mendapatkan data yang akan diperlukan dalam penelitian ini, digunakan jenis instrumen yaitu: tes kemampuan awal matematika (KAM), tes kemampuan pemahaman, koneksi dan komunikasi matematis. Sedangkan untuk kegiatan pembelajaran dibuat rencana pembelajaran dan LKS untuk kelas eksperimen pertama yaitu model pembelajaraan kooperatif tipe STAD dan untuk kelas eksperimen kedua dengan model pembelajaran kooperatif tipe TAI yang masing-masing disertai dengan soal-soal latihan pemahaman matematis, koneksi matematis dan komunikasi matematis.

Data yang terkumpul dianalisis dengan menggunakan teknik statistik deskriptif dan statistik inferensial. Analisis statistik deskriptif dimaksudkan untuk mendeskripsikan kemampuan awal matematika serta kemampuan pemahaman, koneksi dan komunikasi matematis. Analisis statistik inferensial ini dimaksudkan untuk menguji hipotesis dengan uji-t yang diawali dengan menguji persyaratan statsitik yang diperlukan sebagai dasar dalam pengujian hipotesis antara lain uji normalitas dan homogenitas.

\section{HASIL DAN PEMBAHASAN}

\section{A. Hasil Penelitian}

Pemberian tes KAM diawal digunakan untuk mengetahui kesetaraan sampel penelitian dan untuk mengetahui kemampuan awal matematika siswa atau pengetahuan matematika yang telah dimiliki siswa sebelum proses pembelajaran dalam penelitian ini. Hasil tes KAM terlihat pada tabel berikut:

Tabel 2. Tes Kemampuan Awal Matematika (KAM)

\begin{tabular}{ccccc}
\hline \multirow{2}{*}{ KAM } & $\begin{array}{c}\text { Model } \\
\text { Kooperatif }\end{array}$ & Rerata & $\begin{array}{c}\text { Simpangan } \\
\text { Baku }\end{array}$ & N \\
\hline \multirow{2}{*}{ Tinggi } & Tipe STAD & 29,78 & 3,03 & 23 \\
\cline { 2 - 5 } & Tipe TAI & 30,00 & 2,15 & 23 \\
\hline \multirow{2}{*}{ Rendah } & Tipe STAD & 12,57 & 1,97 & 23 \\
\cline { 2 - 5 } & Tipe TAI & 12,26 & 2,80 & 23 \\
\hline
\end{tabular}

(Sumber: Data Primer, Tahun: 2019) 
Histogram: Jurnal Pendidikan Matematika, 4(1), 2020 - 37

Amiruddin', Esterina Natalia Paindan²

Tabel 2 memberikan gambaran bahwa skor rerata KAM kelompok tipe STAD dan tipe TAI relatif sama. Selanjutnya, dilakukan uji-t untuk mengetahui ada atau tidak adanya perbedaan rerata kedua kelompok berdasarkan KAM.

Tabel 3. Analisis Uji-t KAM berdasarkan Model Pembelajaran

\begin{tabular}{|c|c|c|c|c|}
\hline KAM & Model Kooperatif & Rata-rata & $\begin{array}{c}\text { Sig. } \\
\text { (2-tailed) }\end{array}$ & $\mathbf{H}_{\mathbf{0}}$ \\
\hline \multirow{2}{*}{ Tinggi } & STAD & 29,78 & \multirow{2}{*}{0,780} & \multirow{2}{*}{ Diterima } \\
\hline & TAI & 30,00 & & \\
\hline \multirow{2}{*}{ Rendah } & STAD & 12,57 & \multirow{2}{*}{0,672} & \multirow{2}{*}{ Diterima } \\
\hline & TAI & 12,26 & & \\
\hline
\end{tabular}

(Sumber: Data Primer, Tahun: 2019)

Berdasarkan hasil perhitungan yang disajikan pada Tabel 3, pada nilai probabilitas (sig.) dapat disimpulkan bahwa tidak terdapat perbedaan yang signifikan antara skor KAM siswa pada kelompok eksperimen pertama (tipe STAD) dan kelompok eksperimen kedua (tipe TAI) ditinjau dari model pembelajaran. Kesimpulan ini menunjukkan bahwa penelitian ini diawali dengan kondisi KAM siswa yang relatif sama kedua model kooperatif.

Analisis data kemampuan pemahaman matematis, data kemampuan akhir kemampuan pemahaman matematis diperoleh melalui skor gain ternormalisasi (N-Gain). Berdasarkan skor $\mathrm{N}-$ Gain akan dilakukan uji perbedaan rerata kemampuan pemahaman matematis berdasarkan model pembelajaran menggunakan uji-t. Sebelum menggunakan uji-t terlebih dahulu dilakukan uji normalitas data dan uji homogenitas varians kedua kelompok data.

Uji normalitas menggunakan uji Kolmogorov-Smirnov Z (K-S Z) terhdap kedua kelompok data, diperoleh bahwa nilai probabilitas (sig.) secara umum skor N-Gain kemampuan pemahaman matematis menurut kategori KAM (tinggi dan rendah) dan kelompok model pembelajaran kooperatif (tipe STAD dan tipe TAI) secara keseluruhan lebih besar dari 0,05 . Ini berarti hipotesis nol diterima dengan kata lain data $\mathrm{N}$-Gain kemampuan pemahaman matematis pada kedua kelompok berdistribusi normal.

Uji homogenitas varians dilakukan uji Levene diperoleh nilai probabilitas (sig.) pada KAM tinggi dan rendah lebih besar dari 0,05, sehingga hipotesis nol diterima dengan kata lain varians populasi dari data N-Gain kemampuan pemahaman matematis pada KAM tinggi dan rebdag adalah homogen.

Selanjutnya untuk mengetahui perbedaan rerata kedua kelompok sampel berdasarkan KAM tinggi dilakukan uji perbedaan rerata skor $\mathrm{N}$-Gain kemampuan pemahaman matematis ISSN: 2549-6700 (print), ISSN 2549-6719 (online) 
Histogram: Jurnal Pendidikan Matematika, 4(1), 2020 - 38

Amiruddin', Esterina Natalia Paindan²

menggunakan uji-t. sedangkan untuk KAM rendah menggunakan uji-t'. Rangkuman hasil uji perbedaan rerata tersebut dapat dilihat pada tabel berikut:

Tabel 4. Analisis Uji-t Kemampuan Pemahaman Matematis

\begin{tabular}{ccccc}
\hline \multirow{2}{*}{ KAM } & Model Kooperatif & $\begin{array}{c}\text { Rata-rata } \\
\text { N-Gain }\end{array}$ & $\begin{array}{c}\text { Sig. } \\
\text { (2-tailed) }\end{array}$ & Ho \\
\hline \multirow{2}{*}{ Tinggi } & STAD & 0,730 & \multirow{2}{*}{0,007} & Ditolak \\
\cline { 2 - 3 } & TAI & 0,856 & & Ditolak \\
\cline { 2 - 3 } Rendah & STAD & 0,466 & 0,000 & Din \\
\cline { 2 - 3 } & TAI & 0,646 & & \\
\hline
\end{tabular}

(Sumber: Data Primer, Tahun: 2019)

Dengan melihat ringkasan hasil analisis pada Tabel 4, nilai t dan t' probabilitas (sig.) pada masing-masing kategori KAM (tinggi dan rendah) untuk kedua model kooperatif lebih kecil dari taraf signifikansi 0,05 yang ditetapkan, sehingga hipotesis nol ditolak. Dengan kata lain terdapat perbedaan yang signifikan antara rerata skor N-Gain kemampuan pemahaman matematis model pembelajaran kooperatif tipe STAD dengan rerata skor N-Gain kemampuan pemahaman matematis model kooperatif tipe TAI ditinjau dari kemampuan awal matematika (KAM). Hasil ini memberikan kesimpulan bahwa terdapat perbedaan yang signifikan antara kemampuan pemahaman matematis siswa yang mendapat model pembelajaran kooperatif tipe STAD dan tipe TAI pada siswa SMP Negeri 14 Balikpapan ditinjau dari kemampuan awal matematika (KAM) tinggi dan rendah. Dengan memperhatikan nilai rerata skor N-Gain kedua kelompok model pembelajaran kooperatif dapat disimpulkan bahwa pemahaman matematis siswa yang mendapat pembelajaran kooperatif tipe TAI lebih baik daripada siswa yang mendapat pembelajaran kooperatif tipe STAD ditinjau dari kemampuan awal matematika (KAM).

Analisis data untuk kemampuan koneksi matematis, untuk Uji normalitas diperoleh hipotesis nol diterima dengan kata lain data N-Gain kemampuan koneksi matematis pada kedua kelompok berdistribusi normal. Uji homogenitas diperoleh hipotesis nol diterima dengan kata lain varians populasi dari data $\mathrm{N}$-Gain koneksi matematis pada KAM tinggi dan rendah adalah homogen

Selanjutnya untuk mengetahui ada atau tidaknya perbedaan rerata kedua kelompok sampel berdasarkan KAM tinggi dan rendah dilakukan uji perbedaan rerata skor N-Gain kemampuan 


\section{Histogram: Jurnal Pendidikan Matematika, 4(1), 2020 - 3}

Amiruddin', Esterina Natalia Paindan²

koneksi matematis menggunakan uji-t. Rangkuman hasil uji perbedaan rerata tersebut dapat dilihat pada tabel berikut:

Tabel 5. Analisis Uji-t Kemampuan Koneksi Matematis

\begin{tabular}{|c|c|c|c|c|}
\hline KAM & Model Kooperatif & $\begin{array}{c}\text { Rata-rata } \\
\text { N-Gain }\end{array}$ & $\begin{array}{c}\text { Sig. } \\
\text { (2-tailed) }\end{array}$ & $\mathbf{H}_{\mathbf{0}}$ \\
\hline \multirow{2}{*}{ Tinggi } & STAD & 0,692 & \multirow{2}{*}{0,289} & \multirow{2}{*}{ Diterima } \\
\hline & TAI & 0,754 & & \\
\hline \multirow{2}{*}{ Rendah } & STAD & 0,494 & \multirow{2}{*}{0,000} & \multirow{2}{*}{ Ditolak } \\
\hline & TAI & 0,631 & & \\
\hline
\end{tabular}

(Sumber: Data Primer, Tahun: 2019)

Dengan melihat ringkasan hasil analisis pada Tabel 5, nilai t probabilitas (sig.) pada kategori KAM tinggi untuk kedua model kooperatif lebih besar dari taraf signifikansi 0,05 yang ditetapkan, sehingga hipotesis nol diterima, dengan kata lain tidak terdapat perbedaan yang signifikan antara rerata skor N-Gain kemampuan koneksi matematis model pembelajaran kooperatif tipe STAD dengan rerata skor N-Gain koneksi matematis model kooperatif tipe TAI ditinjau dari kemampuan awal matematika tinggi. Sedangkan pada kategori KAM rendah untuk kedua model pembelajaran kooperatif lebih kecil dari taraf signifikansi 0,05 yang ditetapkan, sehingga hipotesis nol ditolak, dengan kata lain terdapat perbedaan yang signifkan antara rerata skor N-Gain kemampuan koneksi matematis model pembelajaran kooperatif tipe STAD dengan rerata skor N-Gain kemampuan koneksi matematis model kooperatif tipe TAI ditinjau dari kemampuan awal matematika. Hasil ini memberikan kesimpulan bahwa pada KAM tinggi, tidak terdapat perbedaan antara kemampuan koneksi matematis siswa model pembelajaran kooperatif tipe STAD dengan tipe TAI, sedangkan pada KAM rendah, terdapat perbedaan antara kemampuan koneksi matematis siswa model pembelajaran kooperatif tipe STAD dengan tipe TAI. Dengan memperhatikan nilai rerata skor N-Gain kedua kelompok model pembelajaran kooperatif dan KAM dapat disimpulkan bahwa kemampuan koneksi matematis siswa yang mendapat pembelajaran kooperatif tipe TAI lebih baik daripada tipe STAD ditinjau dari ke mampuan awal matematika.

Analisis data untuk kemampuan komunikasi matematis. Uji normalitas diperoleh hipotesis nol diterima dengan kata lain data $\mathrm{N}$-Gain kemampuan komunikasi matematis pada kedua kelompok berdistribusi normal. Uji homogenitas varians diperoleh hipotesis nol diterima 


\section{Histogram: Jurnal Pendidikan Matematika, 4(1), 2020 - 40 \\ Amiruddin', Esterina Natalia Paindan²}

dengan kata lain varians populasi dari data N-Gain komunikasi matematis pada KAM (tinggi dan rendah) adalah homogen.

Selanjutnya untuk mengetahui ada atau tidaknya perbedaan rerata kedua kelompok sampel berdasarkan KAM (tinggi dan rendah) dilakukan uji perbedaan rerata skor N-Gain kemampuan komunikasi matematis menggunakan uji-t. Rangkuman hasil uji perbedaan rerata tersebut dapat dilihat pada tabel berikut.

Tabel 6. Hasil Analisis Uji-t Kemampuan Komunikasi Matematis

\begin{tabular}{|c|c|c|c|c|}
\hline KAM & Model Kooperatif & $\begin{array}{c}\text { Rata-rata } \\
\text { N-Gain }\end{array}$ & $\begin{array}{c}\text { Sig. } \\
(2-t a i l e d)\end{array}$ & $\mathbf{H}_{\mathbf{0}}$ \\
\hline \multirow{2}{*}{ Tinggi } & STAD & 0,82 & \multirow[t]{2}{*}{0,007} & \multirow{2}{*}{ Ditolak } \\
\hline & TAI & 0,84 & & \\
\hline \multirow{2}{*}{ Rendah } & STAD & 0,44 & \multirow{2}{*}{0,000} & \multirow{2}{*}{ Ditolak } \\
\hline & TAI & 0,65 & & \\
\hline
\end{tabular}

(Sumber: Data Primer, Tahun: 2019)

Dengan melihat ringkasan hasil analisis pada Tabel 6, nilai t probabilitas (sig.) pada kategori KAM tinggi dan rendah untuk kedua model pembelajaran kooperatif lebih kecil dari taraf signifikansi 0,05 yang ditetapkan, sehingga hipotesis nol ditolak, dengan kata lain terdapat perbedaan yang signifikan antara rerata skorn N-Gain kemampuan komunikasi matematis model pembelajaran kooperatif tipe STAD dengan rerata skor N-Gain komunikasi matematis model kooperatif tipe TAI ditinjau dari kemampuan awal matematika. Hasil ini memberikan kesimpulan bahwa pada KAM tinggi dan rendah, terdapat perbedaan yang signifikan antara kemampuan komunikasi matematis siswa yang mendapat model pembelajaran kooperatif tipe STAD dengan yang mendapat model pembelajaran kooperatif tipe TAI pada siswa SMP Negeri 14 Balikpapan ditinjau dari kemampuan awal matematika, dengan memperhatikan nilai rerata skor N-Gain kedua kelompok model pembelajaran kooperatif dan KAM dapat disimpulkan bahwa kemampuan komunikasi matematis siswa yang mendapat pembelajaran kooperatif tipe TAI lebih baik daripada siswa yang mendapat pembelajaran kooperatif tipe STAD ditinjau dari kemampuan awal matematika.

\section{B. Pembahasan}

Dalam penelitian ini kriteria pengelompokkan KAM berdasarkan 27\% kelompok atas (tinggi) dan 27\% kelompok bawah (rendah). Berdasarkan pengelompokkan KAM tersebut, 


\section{Histogram: Jurnal Pendidikan Matematika, 4(1), 2020 - 41 Amiruddin', Esterina Natalia Paindan²}

dalam penelitian ini model pembelajaran kooperatif tipe STAD sebanyak 46 siswa dari 2 kelas, terdiri dari 23 siswa kelompok tinggi dan 23 siswa kelompok rendah, sedangkan pada model pembelajaran kooperatif tipe TAI sebanyak 46 siswa dari 2 kelas, terdiri dari 23 siswa kelompok tinggi dan 23 siswa kelompok rendah.

Dari hasil analisis data KAM untuk kelompok KAM tinggi, siswa yang mendapat model pembelajaran kooperatif tipe STAD memperoleh rerata KAM sebesar 29,78 tidak berbeda secara signifikan dengan rerata KAM siswa yang mendapat model pembelajaran koopeeratif tipe TAI sebesar 30,00. Begitu juga dengan kelompok KAM rendah, siswa yang mendapat model pembelajaran kooperatif tipe STAD memperoleh rerata KAM sebesar 12,57 tidak berbeda secara signifikan dengan rerata KAM siswa yang mendapat model pembelajaran kooperatif tipe TAI sebesar 12,26. Kesimpulannya bahwa kedua kelompok eksperimen memiliki rerata KAM yang relatif sama sebelum mendapat pembelajaran.

Hasil uji perbedaan peningkatan kemampuan pemahaman matematis berdasarkan model pembelajaran dan KAM menunjukkan bahwa model pembelajaran dan KAM memberikan pengaruh yang signifikan terhadap perbedaan peningkatan kemampuan pemahaman matematis siswa. Hasil penelitian menunjukkan bahwa pada kelompok KAM tinggi rerata N-Gain kemampuan pemahaman matematis siswa yang mendapat model pembelajaran kooperatif tipe TAI sebesar 0,856 lebih besar dari siswa yang mendapat model pembelajaran kooperatif tipe STAD sebesar 0,730. Sedangkan pada kelompok KAM rendah rerata N-Gain kemampuan pemahaman matematis siswa yang mendapat model pembelajaran kooperatif tipe TAI sebesar 0,646 lebih besar dari model pembelajaran kooperatif tipe STAD sebesar 0,466. Ini menunjukkan bahwa model pembelajaran kooperatif tipe TAI lebih baik untuk meningkatkan kemampuan pemahaman matematis dibandingkan dengan model pembelajaran kooperatif tipe STAD.

Pada Hasil penelitian kemampuan koneksi matematis siswa menunjukkan bahwa pada KAM tinggi rerata N-Gain yang mendapat model pembelajaran kooperatif tipe TAI sebesar 0,754 lebih besar dari siswa yang mendapat model pembelajaran kooperatif tipe STAD sebesar 0,692. Sedangkan pada kelompok KAM rendah rerata N-Gain kemampuan koneksi matematis siswa yang mendapat model pembelajaran kooperatif tipe TAI sebesar 0,631 lebih besar dari siswa yang mendapat model pembelajaran kooperatif tipe STAD sebesar 0,494. Hal ini menunjukkan bahwa model pembelajaran kooperatif tipe TAI lebih baik untuk meningkatkan 


\section{Histogram: Jurnal Pendidikan Matematika, 4(1), 2020 - 42 \\ Amiruddin', Esterina Natalia Paindan²}

kemampuan koneksi matematis dibandingkan dengan model pembelajaran kooperatif tipe STAD.

Hasil uji perbedaan peningkatan kemampuan komunikasi matematis berdasarkan model pembelajaran dan KAM menunjukkan bahwa model pembelajaran dan KAM memberikan pengaruh yang signfikan terhadap perbedaan peningkatan kemampuan komunikasi matematis siswa. Hasil penelitian menunjukkan bahwa pada kelompok tinggi rerata N-Gain kemampuan komunikasi matematis siswa yang mendapat model pembelajaran kooperatif tipe TAI sebesar 0,754 lebih besar dari siswa yang mendapat model pembelajaran kooperatif tipe STAD sebesar 0,692. Sedangkan pada KAM rendah rerata N-Gain kemampuan komunikasi matematis siswa yang mendapat model pembelajaran kooperatif tipe TAI sebesar 0,631 lebih besar dari siswa yang mendapat model pembelajaran kooperatif tipe STAD sebesar 0,494. Berdasarkan hasil tersebut menunjukkan bahwa model pembelajaran kooperatif tipe TAI lebih baik untuk meningkatkan kemampuan komunikasi matematis siswa dibandingkan dengan model pembelajaran kooperatif tipe STAD.

Berdasarkan hasil uji komparasi pemahaman, koneksi, dan komunikasi matematis yang ditinjau dari kemampuan awal matematika (rendah dan tinggi) dapat dinyatakan bahwa model pembelajaran tipe TAI lebih baik daripada model pembelajaran kooperatif tipe STAD, hal ini disebabkan pembelajaran matematika dengan menggunakan model pembelajaran kooperatif tipe TAI memberikan keadaan yang lebih aktif dikarenakan siswa dituntut untuk dapat memecahkan masalah secara individual terlebih dahulu kemudian dilanjutkan secara berkelompok sehingga pemahaman, koneksi serta komunikasi matematis pada model pembelajaran kooperatif tipe TAI lebih baik dari model pembelajaran kooperatif tipe STAD. Hasil penelitian ini sejalan dengan penelitian (Harsanti, 2017) dengan hasil penelitian menunjukkan kelas yang diajarkan dengan menggunakan model pembelajaran TAI memiliki rata-rata lebih baik bila dibandingakan dengan kelas yang diajarkan dengan menggunakan model pembelajaran tipe STAD. Kemudian penelitian ini diperkuat lagi dengan penelitian yang dilakukan oleh (Nisa \& Hanggara, 2017) dengan hasil penelitian penerapan pembelajaran dengan menggunakan model pembelajaran TAI memberikan hasil belajar yang lebih baik daripada siswa yang menggunakan model pembelajaran STAD ditinjau dari kemampuan awal siswa, model pembelajaran TAI dan STAD memberikan pengaruh yang berbeda terhadap hasil belajar matematika.

ISSN: 2549-6700 (print), ISSN 2549-6719 (online) 


\section{Histogram: Jurnal Pendidikan Matematika, 4(1), 2020 - 43}

\section{Amiruddin', Esterina Natalia Paindan²}

\section{KESIMPULAN DAN SARAN}

\section{A. Kesimpulan}

Berdasarkan rumusan masalah, hasil penelitian dan pembahasan seperti yang telah dikemukakan pada bab sebelumnya, diperoleh kesimpulan bahwa kemampuan pemahaman, koneksi dan komunikasi matematis siswa dalam penerapan model pembelajaran kooperatif tipe TAI lebih baik daripada model pembelajaran kooperatif tipe STAD pada siswa SMP Negeri 14 Balikpapan ditinjau dari kemampuan awal matematika.

\section{B. Saran}

Berdasarkan kesimpulan di atas, maka peneliti menyarankan beberapa hal yang perlu diperhatikan: 1). Bagi guru diharapkan mengimplementasikan pembelajaran matematika dengan model pembelajaran kooperatif tipe STAD dan tipe TAI berdasarkan hasil dan temuan dalam penelitian ini, terutama pada kemampuan pemahaman, koneksi, dan komunikasi matematis siswa; 2). Bagi siswa dalam meningkatkan kemampuan pemahaman, koneksi dan komunikasi matematis, diharapkan agar lebih memperhatikan aktifitasnya dalam proses pembelajaran agar lebih mudah memahami materi yang diajarkan baik pada saat guru menerangkan maupun pada saat bersama-sama dengan kelompoknya masing-masing; 3). Bagi peneliti selanjutnya yang akan melakukan penelitian sejenis ini, agar dapat mengembangkan lebih jauh lagi tentang perbandingan kemampuan pemahaman, koneksi, dan komunikasi matematis pada masing-masing aspek.

\section{DAFTAR PUSTAKA}

Harsanti, A. G. (2017). Perbandingan Model Pembelajaran STAD dengan Model TAI (Team Assisted Individualization) terhadap Hasil Belajar Matematika Siswa Kelas V Sekolah Dasar. Profesi Pendidikan Dasar, 4(1), 12-18. https://doi.org/https://doi.org/10.23917/ppd.v1i1.3279

Heryani, Y., \& Eptiani, M. M. (2016). Peningkatan Kemampuan Koneksi Matematik Peserta

Didik dengan Menggunakan Model Pembelajaran Means Ends Analysis (MEA). JP3M (Jurnal Penelitisn Pendidikan Dan Pengajaran Matematika, 2(2), 171-178.

Hikmah, R. (2017). Penerapan Model Advance Organizer untuk Meningkatkan Kemampuan ISSN: 2549-6700 (print), ISSN 2549-6719 (online) 
Histogram: Jurnal Pendidikan Matematika, 4(1), 2020 - 44

Amiruddin', Esterina Natalia Paindan²

Pemahaman Siswa. SAP (Susunan Artikel Pendidikan), 1(3), 271-280. https://doi.org/10.30998/sap.v1i3.1204

Latipah, E. D. P., \& Afriansyah, E. A. (2018). Analisis Kemampuan Koneksi Matematis Siswa Menggunakan Pendekatan Pembelajaran CTL dan RME. Matematika, 17(1), 1-12. https://doi.org/10.29313/jmtm.v17i1.3691

Maulida, A. R., Suyitno, H., \& Asih, T. S. N. (2019). Kemampuan Koneksi Matematis pada Pembelajaran CONINCON (Constructivism, Integratif and Contextual) untuk Mengatasi Kecemasan SIswa. Prosiding Seminar Nasional Matematika, 2, 724-731. https://journal.unnes.ac.id/sju/index.php/prisma/

Nisa, M. K., \& Hanggara, Y. (2017). Perbandingan model pembelajaran kooperatif tipe stad dengan tai terhadap hasil belajar matematika ditinjau dari kemampuan awal siswa man 1 batam. PYTHAGORAS: Jurnal Pendidikan Matematika, 6 (2), 2017, 6(2), 115-125. https://www.journal.unrika.ac.id/index.php/jurnalphythagoras/article/view/912/863

Putra, H. D., Setiawan, H., Nurdianti, D., Retta, I., \& Desi, A. (2018). Kemampuan Pemahaman Matematis Siswa Smp Di Bandung Barat. Jurnal Penelitian Dan Pembelajaran Matematika, 11(1). https://doi.org/10.30870/jppm.v11i1.2981

Sari, D. P., Nurochmah, N., Haryadi, H., \& Syaiturjim, S. (2016). Meningkatkan Kemampuan Pemahaman Matematis Melalui Pendekatan Pembelajaran Student Teams Achivement Division. Jurnal Riset Pendidikan Matematika, 3(1), 16. https://doi.org/10.21831/jrpm.v3i1.7547

Sriwahyuni, T., Maya, R., \& Amelia, R. (2019). Jurnal Kajian Pembelajaran Matematika. Jurnal Pendidikan, 3(April), 18-23.

Sugiyono. (2011). Metode penelitian pendidikan: pendekatan kuantitatif, kualitatif, dan R\&D. Alfabeta.

Supriadi, N. (2015). Mengembangkan Kemampuan Koneksi Matematis Melalui Buku Ajar Elektronik Interaktif (BAEI) yang Terintegrasi Nilai-Nilai Keislaman. Al-Jabar: Jurnal Pendidikan Matematika, 6(1), 63-73.

Syarifah, L. L. (2017). Analisis Kemampuan Pemahaman Matematis Pada Mata Kuliah Pembelajaran Matematika Sma Ii. Jurnal Penelitian Dan Pembelajaran Matematika, 10(2), 57-71. https://doi.org/10.30870/jppm.v10i2.2031 